Discourse and Communication for Sustainable Education, vol. 10, no. 1, pp. 113-132, 2019

\title{
Use of Interactive Whiteboard in Teaching Mathematics for Sustainability and its Effect on the Role of Teacher
}

\author{
Tamer Kutluca, Murat Yalman, and Ali Tum \\ Dicle University, Diyarbakır, Turkey
}

\begin{abstract}
As interactive whiteboards have been used recently in secondary schools for sustainability, this study on use of interactive whiteboards is considered to be very important in terms of knowing the effects of interactive whiteboards on mathematics lessons, determining the perspectives of teachers as users of the system and increasing the efficiency of the attempts related to the use of interactive whiteboards. In this respect, the purpose of the study was to investigate the use of interactive whiteboard in teaching mathematics for sustainability and to examine its effects on the role of teachers. The qualitative research approach was adopted in the study as it tried to conduct a deep analysis of a situation. The study was conducted with eight secondary school mathematics teachers working in the province of Adiyaman in Turkey. The research data were collected using a semistructured interview form developed by the researchers. Each interview lasted in a period of time ranging from 8 to 14 minutes. The data collected in the study were analyzed using descriptive analysis with a qualitative approach. In the study, the data were interpreted considering the following themes: "The changes created by interactive whiteboards in the process of teaching mathematics", "The facilities provided by the system for mathematics teachers", "The effects of using interactive whiteboards in teaching mathematics on the role of teachers", "The preparations for using interactive whiteboards in teaching mathematics" and "Use of computer software with interactive whiteboards in teaching mathematics". The results obtained in the study revealed that the teachers were not sufficiently informed or directed regarding the use of whiteboards in teaching mathematics or provided with in-service training support which they needed in relation to the use of interactive whiteboards especially in teaching mathematics. Current role of teachers existing in accordance with the constructivist educational approach has not changed with the use of interactive whiteboards in teaching mathematics, but this role has only become stronger. Furthermore, it was found that interactive whiteboards in mathematics classes are generally used for mathematical exercises.
\end{abstract}

Keywords: interactive whiteboards, sustainability, teachers of mathematics, the role of a teacher. 


\section{Introduction}

In recent times, extremely rapid development and expansion of information and communication technologies (ICT) and supply of products facilitating human lives have brought about a process which causes radical changes in every aspect of our lives. With this process, technology has become an indispensable part of our lives. The change has become inevitable with great impression on societies (Çoklar \& Kabakçi-Yurdakul, 2017). The systems forming societies have to be adapted to technological developments in order to ensure their sustainability during this process of change, and education for sustainability is the most important one of these systems. Especially, technology has recently been used effectively in the field of education for sustainability. For the purpose of adapting oneself to these changes and developments and fulfilling the requirements of this information era, education technologies are actively used in teaching and learning environments (Cakula, 2011; Egne, 2014; Aydın, 2016; Gynne, \& Persson, 2018; Saraç \& Özarslan, 2017).

Current changes and developments have changed the needs of societies and influenced the qualifications of individuals trained in the way to meet these needs. Modern societies aim to raise individuals who learn how to reach information rather than getting it directly from other sources, who know how and when to use this information and who view the world from a critical perspective (Yilmaz, 2007; Badjanova \& Iliško, 2015). This goal increases the importance of individuals with the ability and capacity to use ICT properly and to use them in the most effective way. In our country, this is obvious when mathematics curricula are examined. The Ministry of National Education (MNE) (2013) supports organization of environments by taking advantage of technology for the purpose of developing skills such as problem solving, establishing communication and reasoning. These education technologies are important as they address all students with different skills and knowledge, restructure teaching environments effectively in line with their needs, provide active participation of students in classes in the processes of learning and teaching and ensure efficient use of teaching time (Gerretson et al., 2010; Salìte, 2015; Saraç \& Özarslan, 2017).

In 2010, the project of Movement to Enhance Opportunities and Technology Improvement, which is also known as the FATIH project in Turkey, was put into force with the cooperation of the MNE and the Ministry of Transportation, Maritime Affairs and Communication. Within the scope of this project, one of such instructional technologies which is known as interactive whiteboard in literature and as smartboard in our country and which was developed by turning traditional blackboards into electronic environments (Birisci \& Calik-Uzun, 2014), is used in class environments. Interactive whiteboards are expected to replace books in future as the teaching material, and they look like a large television display which is touch-operated, which includes all kinds of data inside and which continuously update that data (Kennewell \& Beauchamp, 2007; Tataroglu \& Erduran, 2010).

In 2000, the National Council of Teachers of Mathematics (NCTM) set forth their Principles and Standards for School Mathematics (PSSM) to provide guidelines for teachers to support students in learning important mathematical concepts. Mathematics, which is a complete system on its own, is made up of interrelated structures and connections, and it is an abstract concept involving processes of abstraction and generalization of these structures and connections (Alakoc, 2003). It is extremely hard to learn abstract 
concepts. Students have difficulty in comprehending mathematics, experience misconceptions and thus develop negative attitudes towards mathematics.

Kutluca (2009) point out that the computer-aided method of teaching should be used to eliminate such negative issues. Computer-aided teaching practices can easily be implemented by using interactive whiteboards for sustainability. When used effectively, interactive whiteboards provide several advantages such as making visual quality prominent, allowing use of activities such as animations, encouraging student interaction and providing a broader perspective for mathematics teaching (Basibuyuk et al., 2014; Kutluca, 2017). Interactive whiteboards allow using a wide variety of teaching methods and have influence on learning in several aspects by drawing students' attention to the lessons and increasing their motivation and success in the course (Turel, 2012). Mathematics is a course sometimes considered to be harder to learn and teach when compared to other disciplines, and it is thus necessary to investigate the effects of teaching this course in interactive environments with the help of whiteboards.

Within the scope of the study, computer-based and multifaceted teaching practices based on pedagogical approaches for sustainability would be implemented in class by using interactive whiteboards (Kutluca, 2017). These practices were expected to bring in different perspectives re-grading mathematics classes, to make the course more enjoyable for students. Secondly, it is to include alternatives for the students experiencing difficulty in understanding mathematics through traditional teaching methods and strategies, that are suitable to education for sustainability (Makrakis \& Kostoulas-Makrakis, 2012). Therefore, teachers have an important role in teaching by using interactive whiteboards in class. The reason is that it is important for teachers to know the instructional technological tool well, so that they can plan the teaching process, make the teaching process efficient and permanent and enrich the visual contents (Mayer, 2003; Kocak \& Gulcu, 2013; Gynne \& Persson, 2018). The efficiency and success of interactive whiteboard practices which create opportunities for computer-based teaching in important fields of education, especially in mathematics classes, mainly depend on the attitudes and self-efficacies of teachers regarding technology-supported education systems (Ekici, 2008; Tataroglu, 2009; Torff \& Tirotta, 2010; Demir \& Bozkurt, 2011). In addition, the teachers need to have the technological and pedagogical competences to integrate the interactive whiteboard technology within the teaching environment through the process.

When the literature is examined, it is seen that there are several studies carried out to determine teachers' views about whiteboards. Most of these studies were conducted under various themes such as opinions, attitudes, perceptions and self-efficacies of teachers regarding the use of interactive whiteboards; evaluation of pilot application processes carried out within the scope of FATIH project; problems, needs and suggested solutions; applications within the scope of different curricula; effects of use of whiteboards on the permanency of learning and on learners' motivation; advantages and disadvantages of whiteboards; effects of the use of whiteboards on students' success, attitudes and motivation; and influence of the use of whiteboards on the role of teachers and on in-class interactions (Kennewell \& Beauchamp, 2008; Demir \& Bozkurt, 2011; Kocak \& Gulcu, 2013, Durak, Sarıtepeci, \& Çakır, 2016; Kutluca, 2017).

In relation to the use of whiteboards in mathematics, there are several other studies carried out on the effects of interactive whiteboards on the success, attitudes and motiva- 
tion of students in higher education institutions (Akcayir, 2011); reflections on use of interactive whiteboards in secondary school education in the views of teachers and students (Basibuyuk et al, 2014; Birisci \& Calik-Uzun, 2014); effects of whiteboards on students' academic achievement, and their attitudes towards the course of mathematics (Tataroğlu, 2009; Kaya, 2013); self-efficacies of mathematics teachers regarding technology integration into the elementary and secondary school curricula (Demir \& Bozkurt, 2011; Çoklar \& Kabakçi-Yurdakul, 2017); effects of whiteboard use on students' achievement in mathematics; and use of interactive whiteboards on success in mathematics (Ekici, 2008; Gündüz \& Kutluca, 2019). Obviously, there is a limited number of studies in our country regarding the use of interactive whiteboards in teaching mathematics especially in primary and secondary school education. The reason for this limited number of studies is thought to be because use of interactive whiteboards in secondary education has become popular recently. Despite all these studies, Makraskis \& Kostoulas-Makrakis (2012) state that using education for sustainable learning is a big challenge and use of ICT in mathematics is even a bigger one.

As use of interactive whiteboards in secondary schools is quite new, the present study is considered to be important in terms of knowing the effects of interactive whiteboards in mathematics lessons, in determining teachers' views about whiteboards and contributing to the effectiveness and efficiency of related attempts. In this respect, the purpose of this study was to determine the use of interactive whiteboards in teaching mathematics for sustainability and to examine its effects on the role of teachers as users of interactive whiteboards in class.

\section{Teacher's Role}

Unlike the traditional understanding in education, the teacher in sustainable education is a person who organizes and gradually transfers information to students and who guides them in their process of structuring their knowledge which they have developed via their interaction with the environment by making use of their background knowledge (Akçay, 2017; Kutluca, 2009). A teacher aims not only to increase his or her students' success at school but also prepare them for real life via sustainable education. For this purpose, the teacher has to choose the teaching strategies that will relate real life to sustainable education.

In order for teachers to become more effective, they need to use different teaching methods in the teaching process, to use a student-centred approach, to use a clear and comprehensible language, to make use of technology when necessary, to constantly update their teaching in accordance with students' needs and to encourage their students to take responsibility for their own learning (Strong, Gargani, \& Hacifazlioğlu, 2011). Teachers should also pay attention to being prepared for lessons, personally talk to and guide students who behave in a way to disturb the class atmosphere and demonstrate consistent and objective behaviours in class (Englehart, 2013). In addition, considering the fact that students may lose their motivation and interest in class, teachers must avoid providing long instructions in class and carry out activities involving effective, interactive and reflective thoughts.

The Smartboard has positive effects on the teacher's role including visualizing the lesson subject, concretizing abstract subjects, attracting students' attention, helping 
increase active participation in class and making more productive use of class time. However, use of the smartboard in class is also reported to have several negative effects on the teacher's role by making class management difficult and making it difficult for the teacher to be adopted by students. Despite all, the idea that information and communication technologies will support the teacher's role and the learner's role is approved by everyone, and there are attempts to determine and overcome the deficiencies regarding this problem.

With the adoption of modern approaches and especially with the development of technology, use of information and communication technologies is now fairly common in educational environments. When information and communication technologies are considered within the context of teaching-learning processes, these technologies not only support the teacher's role and the learner's role by helping the teacher reveal his or her responsibilities, beliefs, knowledge, skills and experiences regarding what and how to teach, but also have influence on the decisions regarding the teaching and learning process and thus cause the teacher to show both affective and cognitive reactions (Darby, 2007). It is thought therefore, that teachers from different fields of education might have different views and practices regarding the process of integrating technological tools into their lessons. The reason is that, as pointed out by Glover and Miller (2002), the contribution of interactive smartboards, one of such technological tools, to the teaching-learning process varies depending on how the teacher will use this technology (Birişçi \& Çalık-Uzun, 2014). For this reason, teachers' views should be taken into account regarding the integration of information and communication technologies into education, which is considered to be an educational reform for developing countries.

\section{Research Model}

The qualitative research approach was used in this study as it tried to conduct a deep analysis of a situation. Qualitative research does not only create an opportunity to examine what a certain concept is and to obtain detailed results regarding that subject but also puts the causes of these results into the forefront (Merriam, 2013). This study, which was conducted using the qualitative research approach, tried to reveal the perspectives, views and experiences of mathematics teachers regarding a phenomenon, concept or situation in line with the research purpose.

\section{Study Group}

Eight mathematics teachers working in secondary schools in the central district of the province of Adiyaman in Turkey constituted the study group of this research. Within the scope of this study, the teachers were selected based on the criterion of having an interactive whiteboard in their classes. Following the preliminary interviews held with the participants, they indicated that they voluntarily participated in the study. In order to keep secret the identities of the mathematics teachers in the study group, they were coded as $\mathrm{M}_{1}, \mathrm{M}_{2}$ and ... Information on the study group is provided in Table 1 . Table 1 presents Information about the study group. 
Table 1

Information About the Study Group

\begin{tabular}{cccc}
\hline Teacher & Gender & Experience in Teaching & Degree of Education \\
\hline $\mathrm{M}_{1}$ & Female & 15 & University Graduate \\
\hline $\mathrm{M}_{2}$ & Male & 15 & University Graduate \\
\hline $\mathrm{M}_{3}$ & Female & 6 & University Graduate \\
\hline $\mathrm{M}_{4}$ & Male & 35 & University Graduate \\
\hline $\mathrm{M}_{5}$ & Male & 10 & University Graduate \\
\hline $\mathrm{M}_{6}$ & Female & 12 & University Graduate \\
\hline $\mathrm{M}_{7}$ & Male & 5 & University Graduate \\
\hline $\mathrm{M}_{8}$ & Male & 3 & University Graduate \\
\hline
\end{tabular}

\section{Data Collection Procedure}

The data in the study were collected using the semi-structured interview technique. The interview questions were prepared by the researchers by reviewing the related literature and by asking views of field experts and those in the field of information technology. Concurrently, a preliminary interview was held with four teachers to check the clarity and comprehensibility of the interview questions. During the interviews, the teachers were directed the following questions:

1. What kind of changes has use of interactive whiteboards caused in teaching mathematics? (Teacher-student motivation, attitudes towards mathematics, quality of lessons, students' success, class management details...)

2. What kind of pedagogical problems did you experience while using interactive whiteboards in teaching mathematics? What were the causes of these problems?

3. How did use of interactive whiteboards in mathematics lessons influence the teacher's role?

4. Do you make any preparations for using interactive whiteboard in teaching mathematics?

- If so, what kind of preparations are they?

- If not, why not?

5. Do you use any mathematics software on the interactive whiteboard while teaching mathematics?

- If so, what kind of software do you use? If not, why not?

6. For what purposes do you use interactive whiteboard in your classes? (Motivation, lecture, practice, repetition)

Each interview lasted about 8 to 14 minutes. All the interviews were recorded using a digital audio recorder.

\section{Data Analysis}

The interviews recorded using a digital audio recorder were transcribed for data analysis. In this process, special attention was paid to avoiding any loss of the recorded data. The transcribed data were subjected to descriptive analysis using a qualitative approach. Furthermore, data were categorized into themes, and a frequency table was 
obtained using codes. In addition, direct quotations from the interviews held with the teachers were also included.

\section{Findings}

The findings obtained in the study are presented in six categories. These categories were as follows: "The changes created by interactive whiteboards in the process of teaching mathematics", "The facilities provided by the system for mathematics teachers", "The effects of using interactive whiteboards in teaching mathematics on the role of teachers", "The preparations for using interactive whiteboards in teaching mathematics", "Use of computer software with interactive whiteboards in teaching mathematics" and "frequencies and purposes of use of interactive whiteboards in teaching mathematics".

\section{Changes Caused by Use of Interactive Whiteboards in the Process of Teaching Mathematics}

Considering both the fundamental elements of the education process and the views of teachers, the changes were coded as "Student motivation", "attitudes towards mathematics", "lesson quality", "student success" and "class management".

Table 2

Changes Caused by Use of Interactive Whiteboards in Teaching Mathematics

\begin{tabular}{lcc}
\hline \multicolumn{1}{c}{ Code } & Teacher & $\mathrm{f}$ \\
\hline Student motivation & $\mathrm{M}_{1} \mathrm{M}_{3} \mathrm{M}_{5} \mathrm{M}_{7} \mathrm{M}_{8}$ & 5 \\
\hline Attitudes towards mathematics & $\mathrm{M}_{2} \mathrm{M}_{4} \mathrm{M}_{6} \mathrm{M}_{7} \mathrm{M}_{8}$ & 5 \\
\hline Lesson quality & $\mathrm{M}_{2} \mathrm{M}_{4}$ & 2 \\
\hline Student success & $\mathrm{M}_{2} \mathrm{M}_{3} \mathrm{M}_{4} \mathrm{M}_{5} \mathrm{M}_{7} \mathrm{M}_{8}$ & 6 \\
\hline Class management & $\mathrm{M}_{3} \mathrm{M}_{5} \mathrm{M}_{6} \mathrm{M}_{8}$ & 4 \\
\hline
\end{tabular}

When Table 2 is examined, it is seen that regarding the use of interactive whiteboards, the secondary school mathematics teachers reported changes mostly in student success (6), student motivation (5) and attitudes towards mathematics (5). They also indicated that the least observed change was related to the lesson quality (2). Below are sample responses of some of the teachers regarding this category:

“... It increases motivation of low level students as it attracts their attention...” $\left(\mathrm{M}_{1}\right)$

"... when we show the videos broadcasted in EBA on the interactive whiteboard, it sometimes so interesting that motivation of students increases extraordinarily...” $\left(\mathrm{M}_{5}\right)$

“... Actually, we could make our students love mathematics a little bit more. They love interactive whiteboards as they love computers...” ( $\left.\mathrm{M}_{6}\right)$

"... Interactive whiteboard has a tremendous effect on students while teaching mathematics. The children are enthusiastic and in competition with each other as it is a new invention, a priority..." $\left(\mathrm{M}_{4}\right)$ 
"... The lessons go well in the good classes. In worse ones, as I have said before, we lose control a little..." $\left(\mathrm{M}_{8}\right)$

"... With regards to lesson quality, lessons go well in good classes..." $\left(\mathrm{M}_{3}\right)$

"... Hardworking students get the same success even if there is an interactive whiteboard. While, I can say that the middle or low level students also show even a little success...” $\left(\mathrm{M}_{1}\right)$

"... I have not experienced any problem in class management..." $\left(\mathrm{M}_{7}\right)$

"... As our classes are crowded and I cannot have sufficient discipline in lecturing, I do not use it frequently...” $\left(\mathrm{M}_{8}\right)$

Teachers' use of interactive whiteboards in mathematics classes increases motivations of students with middle or low academic achievement and has positive, though little, influence on their success. It is pointed out that interactive whiteboard has positive but not much influence on students' achievement. In addition, the fact that the use of interactive whiteboards has just become popular and that teachers are thus not familiar with this technology has negative effects on their motivations in teaching mathematics. Based on the teachers' comments regarding the use of interactive whiteboards in mathematics, it could be stated that it has positive influence on students' attitudes towards mathematics. Students' attitudes towards the course change in line with the use of interactive whiteboards in class not only because they have familiarity with technology but because they use technology in all kinds of activities in their daily lives.

The teachers' views and experiences revealed that the visibility, concretization and problem-solving capability increased in line with the use of interactive whiteboards in class, and this also increased the lesson quality. This increase in the lesson quality was mostly in favour of the students with high levels of academic achievement. It was seen that the teachers' use of interactive whiteboards resulted in poor class management and thus caused the students to demonstrate undesirable behaviours in class because the teachers failed to use interactive whiteboards efficiently in class, sometimes because the classes were crowded and sometimes because the teachers were too much interested in the interactive whiteboards.

\section{Facilities Provided by Interactive Whiteboards for Teachers}

The category of facilities provided by interactive whiteboards in teaching mathematics were coded as "visual quality, drawings and presentations", "lectures and related questions", "attracting attention", "measurement and evaluation", "time management and productivity", "review of important parts" and "participation in class".

Table 3

Facilities Provided by Interactive Whiteboards for Teachers

\begin{tabular}{lcc}
\hline \multicolumn{1}{c}{ Code } & Teacher & $\mathrm{f}$ \\
\hline Visual quality, drawing and presentations & $\mathrm{M}_{1} \mathrm{M}_{2} \mathrm{M}_{3} \mathrm{M}_{7} \mathrm{M}_{8}$ & 5 \\
\hline Lectures and related questions & $\mathrm{M}_{1} \mathrm{M}_{2}$ & 2 \\
\hline Attracting attention & $\mathrm{M}_{3} \mathrm{M}_{8}$ & 2 \\
\hline & Sequel to Table 3 see on the next page.
\end{tabular}


Sequel to Table 3.

\begin{tabular}{lcc}
\hline Measurement and evaluation & $\mathrm{M}_{4}$ & 1 \\
\hline Time management and productivity & $\mathrm{M}_{6} \mathrm{M}_{7} \mathrm{M}_{8}$ & 3 \\
\hline Review of important parts & $\mathrm{M}_{4}$ & 1 \\
\hline Participation in class & $\mathrm{M}_{2} \mathrm{M}_{6} \mathrm{M}_{8}$ & 3 \\
\hline Preliminary preparation & $\mathrm{M}_{1} \mathrm{M}_{2} \mathrm{M}_{3} \mathrm{M}_{4} \mathrm{M}_{7} \mathrm{M}_{8}$ & 6 \\
\hline
\end{tabular}

When Table 3 is examined, it is seen that the secondary school mathematics teachers indicated the facilities provided by interactive whiteboards mostly as preliminary preparation (6) and visual quality, drawing and presentations (5). They reported views least about measurement and evaluation (1). Below are sample quotes of some of the teachers regarding this category:

$\mathrm{M}_{1}$ : “...it is very easy for the teacher to use an interactive whiteboard; I mean all visuals, presentations, lectures and all appropriate and necessary questions regarding the subjects are available in line with the curriculum. The only thing we should do is to implement it properly and effectively..."

$\mathrm{M}_{2}$ : “...Maybe we take the easy way out, but instead of opening the readymade applications on the interactive whiteboard and writing down the problems one by one, we only solved the questions there..."

$\mathrm{M}_{3}$ : “... Actually, before the interactive whiteboard, the lectures were a little bit limited. Especially, it provides great facility for us while drawing geometric figures... For example, there are different colors, and while drawing a geometric figure on the interactive whiteboard, you can dye it in a different color, and at the same time, you can use any geometric figure as you wish..."

$\mathrm{M}_{4}$ : “... Interactive whiteboard is more useful when you pause it and have your students write the important points and then you reactivate it. We can review important parts again... Our control over the students in class is excellent, and the students listen to us very carefully... We can provide the environment for measuring each of the students' levels of knowledge with the help of the interactive whiteboard. Also, this allows us to see the overall capacity of the students and their human relations better..."

$\mathrm{M}_{6}$ : “... Especially the time we used to spend writing questions during a lesson decreased the quality of the lessons, but now this problem does not exist any longer... We provide higher participation in class.... And this is a facility for us..."

$\mathrm{M}_{7}$ : “... While we are drawing a circle, we mostly fail to draw a perfect one. This is especially a problem we experience with geometric figures. However, with the help of the interactive whiteboard, it is very easy for us to prepare them by using related softwares... Instead of drawing the figures and writing down long mathematical operations on the blackboard one by one, we prepare them at home and go to classroom, which really helps us use our class time more effectively."

When lectures in mathematics, which has an abstract nature, are not concretized, students cannot give meaning to the related concepts. The teachers' views revealed that 
interactive whiteboards provide facilities for teachers in terms of providing visuality, drawing the figures properly, increasing students' participation in class by attracting their attention to lessons, supporting lectures with presentations, solving questions in relation to the lectures, reviewing important points and providing the opportunity to carry out individual evaluation and assessment when necessary. Another advantage was that doing the necessary preliminary preparations was easy for the teachers who wanted to teach their lessons using the interactive whiteboard.

\section{Influence of Use of Interactive Whiteboard in Teaching Mathematics on the Role of the Teacher}

In this category, the following codes were used: "class management and discipline", "current role" and "giving importance to planning and discipline".

Table 4

Influence of Use of Interactive Whiteboard on the Role of the Teacher

\begin{tabular}{lcc}
\hline \multicolumn{1}{c}{ Code } & Teacher & $\mathrm{f}$ \\
\hline Organizer role of the teacher & $\mathrm{M}_{1}$ & 1 \\
\hline Class management and discipline & $\mathrm{M}_{1} \mathrm{M}_{7} \mathrm{M}_{8}$ & 3 \\
\hline Current role & $\mathrm{M}_{1} \mathrm{M}_{2} \mathrm{M}_{3} \mathrm{M}_{8}$ & 4 \\
\hline Use of technology while teaching & $\mathrm{M}_{5} \mathrm{M}_{6}$ & 2 \\
\hline Directive role of the teacher & $\mathrm{M}_{4} \mathrm{M}_{8}$ & 2 \\
\hline
\end{tabular}

When Table 4 is examined, it is seen that the secondary school mathematics teachers indicated the effects of using interactive whiteboards in teaching mostly as the current role (4) and class management and discipline (3) and least as the organizer role of the teacher (1). Below are sample quotes of some of the teachers regarding this category:

$\mathrm{M}_{1}$ : “... The role of the teacher is always to control the class; I mean the teacher is always the control mechanism. This was also true for the interactive whiteboard; for example, it was again a student-centred approach. The students used the interactive whiteboard, and they solved the questions. The teacher only had the organizer role there managing the class..."

$\mathrm{M}_{2}:$ “... The students should comprehend the subjects taught during the lessons. For this purpose, they should analyse themselves well, and you should involve them in the learning process during the lesson. We have a constructivist education system, and the students are supposed to structure the information themselves. Providing information directly on the blackboard is contrary to our educational philosophy, and this new technology should not be used in that wrong way. If a teacher uses it in that way, then this is not different for a student from watching television..."

$\mathrm{M}_{4}$ : "... All the students prepared documents at home to use on the interactive whiteboard in class, and we tried to use these documents together in the classroom..."

$\mathrm{M}_{7}$ : “... If, we regard interactive whiteboards as a tool for playing games in class, it becomes useless. However, when we use it efficiently in accordance 
with its software, I am absolutely sure that the teacher will use class time efficiently and achieve class management and discipline...

$\mathrm{M}_{8}$ : “... Actually, I believe this technology significantly changes the role of the teacher. We still have the teacher role appropriate to the constructive education philosophy, but the interactive whiteboard provided the teacher with the opportunity to have a wider area for using that role. I mean the interactive whiteboard assisted and allowed the teacher to use his or her current teacher's role effectively. Also, the teacher still acts as a guide for students to reach the necessary information in class and achieves class management..."

The teachers' views revealed via the interviews demonstrated that use of interactive whiteboards in mathematics classes did not cause any change in the role of the teacher regarding the current constructive education philosophy. In contrast, it strengthened the characteristics of that role. With the help of the interactive whiteboard, the teacher undertook a role which allowed ensuring class management and discipline, encouraging the students to take a more active part in activities and integrating technology more effectively in education. The interactive whiteboard reduced the burden on teachers and became an educational tool supporting them. Furthermore, it could be stated that this technology has positive effects on the role of the teachers when they have the capacity to use this technology more efficiently.

\section{Preparations for Use of Interactive Whiteboards in Teaching Mathematics}

The teacher will always need to plan the steps in advance to teach mathematics effectively in class and to act accordingly. In this respect, preliminary preparations are a must for the teacher. When the data was obtained from the participants within the framework of this category, they were coded as "the interactive whiteboard as a Material, "books with different lectures loaded on flash memories and question banks compatible with the interactive whiteboard", "checking acquisitions", "Examining EIN (Education Information Network) and Portals" and "Preparing Questions".

Table 5

Teachers' Preparations for Using Interactive Whiteboards in Teaching Mathematics

\begin{tabular}{lcc}
\hline \multicolumn{1}{c}{ Code } & Teacher & $\mathrm{f}$ \\
\hline Interactive whiteboard as a material & $\mathrm{M}_{1}$ & 1 \\
\hline $\begin{array}{l}\text { Books with different lectures loaded on flash memories and } \\
\text { question banks compatible with the interactive whiteboard }\end{array}$ & $\mathrm{M}_{2} \mathrm{M}_{3} \mathrm{M}_{4} \mathrm{M}_{8}$ & 4 \\
\hline Checking acquisitions & $\mathrm{M}_{3}$ & 1 \\
\hline Examining EIN and portals & $\mathrm{M}_{5} \mathrm{M}_{7} \mathrm{M}_{8}$ & 3 \\
\hline Preparing questions & $\mathrm{M}_{4} \mathrm{M}_{6} \mathrm{M}_{8}$ & 3 \\
\hline
\end{tabular}

When Table 5 is examined, it is seen that the secondary school mathematics teachers mentioned use of interactive whiteboards in teaching mathematics mostly in terms of books with different lectures loaded on flash memories and question banks compatible with interactive whiteboards (4), "Examining EIN and portals (3) and preparing questions (3) and least in terms of use of the interactive whiteboard as a material (1) and checking acquisitions. 
(1) Below are sample quotes of some of the teachers regarding this category:

$\mathrm{M}_{1}:$ :... The interactive whiteboard replaced the materials, presentations and other supplementary materials that we used to use in class. But now, we use interactive whiteboards in class as our main material. We used to bring materials into class in the past, but now we don't. We just show these materials on the display. I load drawings on the whiteboard, but I used to have a ruler with me to draw triangles and others on the blackboard. But now, the software itself draws these figures on the whiteboard..."

$\mathrm{M}_{2}$ : “... We have limited resources. And, we have to use only our books because the Ministry of National Education does not provide us with any other resources. And these resources are not included in these interactive whiteboards, so we have to use our books and the interactive whiteboard separately. I wish there were an environment where both of them were integrated. I mean I wish the books given to us were compatible with the interactive whiteboards. I have question banks that I have bought from a book store, and I use them only as documents in class..."

$\mathrm{M}_{5}:$ :... Usually, I checked the videos of EIN before the lessons. I check them in order to find something suitable for our students, and I also look at the portals in EIN..."

$\mathrm{M}_{7}$ : “... I make preparations, and especially for the $8^{\text {th }}$ grade students, I mostly prepare questions and figures in computer and reflect them on the interactive whiteboard. Besides, I search for videos on subjects related to mathematics. And I also have a look at EIN before the lessons..."

$\mathrm{M}_{8}$ : “... Before the lessons, we look at the portals for videos, presentations and activities related to the subject we will teach, and we decide which one we can use. We load the questions we prepare at home in Word format into a flash drive and bring them into class to solve them on the whiteboard. Actually, as there are lots of visual contents in interactive whiteboards, we do not have to look for different materials..."

The teachers prepared some documents on the computer to use in their mathematics classes, checked the outcomes to get prepared before lectures, searched for question banks to solve on the interactive whiteboard and for reference books to introduce the related concepts, examined EIN and portals and watched some videos to provide better instructions in class. In addition, the teachers reported that they did not need any preliminary preparation for some subjects as they used the interactive whiteboard as a material itself.

\section{Use of Computer Software on Interactive Whiteboards While Teaching Mathematics}

Computer software is important for giving meaning to subjects in teaching mathematics. When the data obtained in relation to this category are examined, it is seen that the data were coded as "installed software", "self-development and related efforts", "university graduate degree", "lack of knowledge", "forgetting how to use it in time" and "financial sources". These codes helped explain the reasons why the teachers did not use computer software in teaching mathematics. 
Table 6

Use of Computer Software in Teaching Mathematics

\begin{tabular}{lcccccccc}
\hline \multicolumn{1}{c}{ Teacher } & $\mathrm{M}_{1}$ & $\mathrm{M}_{2}$ & $\mathrm{M}_{3}$ & $\mathrm{M}_{4}$ & $\mathrm{M}_{5}$ & $\mathrm{M}_{6}$ & $\mathrm{M}_{7}$ & $\mathrm{M}_{8}$ \\
\hline $\begin{array}{l}\text { Use the Computer } \\
\text { Software }\end{array}$ & Never & Never & Never & Never & Sometimes & Never & Sometimes & Sometimes \\
\hline
\end{tabular}

When Table 6 is examined, it is seen that five of the teachers did not use any computer software on the interactive whiteboard and that three of them sometimes used computer software. This shows that the teachers did not use computer software actively while teaching Mathematics. Table 7 presents the reasons why the teachers did not use any computer software while teaching mathematics.

Table 7

The Reasons for not Using Computer Software While Teaching Mathematics

\begin{tabular}{lcc}
\hline \multicolumn{1}{c}{ Code } & Teacher & $\mathrm{f}$ \\
\hline Installed software & $\mathrm{M}_{1}$ & 1 \\
\hline Self-improvement and related effort & $\mathrm{M}_{1} \mathrm{M}_{8}$ & 2 \\
\hline University graduate degree & $\mathrm{M}_{2} \mathrm{M}_{6} \mathrm{M}_{7}$ & 3 \\
\hline Lack of knowledge & $\mathrm{M}_{1} \mathrm{M}_{3}$ & 2 \\
\hline Forgetting how to use it in time & $\mathrm{M}_{5} \mathrm{M}_{6} \mathrm{M}_{7} \mathrm{M}_{8}$ & 4 \\
\hline Financial sources & $\mathrm{M}_{4}$ & 1 \\
\hline
\end{tabular}

When Table 7 is examined, it is seen that there were several reasons why the teachers did not use any computer software on the interactive whiteboard while teaching mathematics. It was found that the teachers used the (1) previously installed software, if any, in the interactive whiteboard. In addition, it was revealed that some of the teachers did not have any knowledge about different software; however, they pointed out that it would be very beneficial in teaching mathematics if they had learned how to use them. Separately, it was seen that they did not make any effort to develop themselves in this field (2); that they did not have any knowledge about that need (2); and that they did not have any related training during their university education (3). It was clearly indicated by the teachers who had knowledge about such computer software that they learned them during their university education but forgot how to use them in time as they did not use in the process (4). Lastly, the teacher coded as $\mathrm{M}_{4}$ did not use computer software due to lack of necessary financial sources.

(1) Below are sample quotes of some of the teachers regarding this category:

$\mathrm{M}_{1}$ : “... We use what is already installed in our interactive whiteboards. If any software is provided, I spend time and make effort to learn and use it. I am a person who always likes to improve himself/herself. Actually, neither I nor anyone else has ever made such an effort..."

$\mathrm{M}_{2}$ : “... I do not use any computer software while teaching mathematics because I have never seen or used any before. We have not been provided any training during our education at university..."

$\mathrm{M}_{3}$ : “... I think you are talking about mathematics software, especially geometry software, but to tell the truth, I do not know anything about them, 
and actually, I have never made any investigation about them. I have only heard about them, but I haven't used any of them at all as I don't know much about how they exactly work..."

$\mathrm{M}_{4}$ : “... We do not use any software as people around here already suffer from poverty. We only use the documents I have mentioned because others are too expensive for the students..."

$\mathrm{M}_{5}$ : “... I know Geogebra, which I first heard about during my university education. I used that software once in the past, and since then, I haven't used it again. Thus, I now don't remember how to use it. In general, I haven't used such software in my geometry or mathematics lessons..."

$\mathrm{M}_{6}:$ : ... No, I don't use any software. During our university education, about fourteen or fifteen years ago, we learned something about such software, but actually we have forgotten them all. We learned Matematica and then Geogebra. But, I don't remember much about how to use them as we don't use them any longer..."

$\mathrm{M}_{7}$ : “... I want to use them, but I think I don't remember much about them. I mean I don't use the software which I learned during my university education. Actually, we only show students the things we mainly prepare using Word or Excel. I do not use mathematics software actively. I mean this is partly because of forgetting how to use them..."

$\mathrm{M}_{7}$ : “... I know a few software related to the course of mathematics, but I learned them superficially, and actually, I don't use them as I don't know how to use them properly. Maybe, it would be more effective if we used them, but as our education system is exam-oriented, it does not allow us to use such software due to the restricted time..."

\section{Frequency and Purposes of Use of Interactive Whiteboards in Mathematics}

Today, the mathematics curricula give importance to use of technology in classes. Table 8 presents the frequencies and percentages showing the teachers' use of interactive whiteboards for five course hours on weekly basis.

Table 8

Weekly Frequencies of Use of Interactive Whiteboards During Lessons

\begin{tabular}{lll}
\hline & Teacher & $\mathrm{f}$ \\
\hline Five course hours & $\mathrm{M}_{1} \mathrm{M}_{2}$ & 2 \\
\hline Between 3 to 5 course hours & $\mathrm{M}_{7} \mathrm{M}_{8}$ & 2 \\
\hline Between 2 to 3 course hours & $\mathrm{M}_{3} \mathrm{M}_{4} \mathrm{M}_{5} \mathrm{M}_{6}$ & 4 \\
\hline
\end{tabular}

When Table 8 is examined, it is seen that the teachers mostly used the interactive whiteboards for 2 to 3 course hours of a total of five course hours in a week (4). The reason for the low frequency of use of interactive whiteboards could be explained by the fact that the teachers did not consider themselves to be efficient in terms of use of these interactive whiteboards. 
Table 9 shows the codes and frequencies related to the participants' responses regarding the purposes of use of interactive whiteboards during the lessons.

Table 9

The Purposes of Use of Interactive Whiteboards in Mathematics Class

\begin{tabular}{lcc}
\hline \multicolumn{1}{c}{ Code } & Teacher & $\mathrm{f}$ \\
\hline Attention and motivation & $\mathrm{M}_{1} \mathrm{M}_{3} \mathrm{M}_{7} \mathrm{M}_{8}$ & 4 \\
\hline Practicing activities & $\mathrm{M}_{1} \mathrm{M}_{4}$ & 2 \\
\hline Solving questions and extra activities & $\mathrm{M}_{1} \mathrm{M}_{2} \mathrm{M}_{3} \mathrm{M}_{4} \mathrm{M}_{5} \mathrm{M}_{6} \mathrm{M}_{8}$ & 7 \\
\hline Reviewing the lesson subjects & $\mathrm{M}_{2} \mathrm{M}_{5} \mathrm{M}_{6}$ & 3 \\
\hline
\end{tabular}

When Table 9 is examined, it is seen that most of the teachers carried out activities like solving questions and dealing with extra activities while using the interactive whiteboard in their mathematics classes (7). The teachers used the interactive whiteboard least for lecturing. (2). Furthermore, the teachers reported that they did not use interactive whiteboards at all while teaching and that they preferred to teach the subjects without using extra materials on the whiteboards. Below are sample quotes of some of the teachers regarding the purposes of use of interactive whiteboards during the lessons:

$\mathrm{M}_{1}$ : “... We use it to contribute to our teaching process, to increase students' motivation and to solve mathematical problems and so on..."

$\mathrm{M}_{2}$ : “... I only use it for extra activities and reviewing the lesson subjects. The only thing I can do is practicing. I don't know what else to do because I didn't received any related training during my university education. If there are resource, I haven't heard about them. Actually, I look at EIN, but there are only questions and videos covering the lesson topics. But, I can already teach these things included in those videos..."

As can be understood from the views of the teacher coded as $M_{2}$, the teachers had not received any training they needed for using interactive whiteboards in their fields of teaching:

$\mathrm{M}_{2}:$ "... Usually, I use the interactive whiteboard like a traditional blackboard while teaching something, and I draw students' attention by drawing something in different colors. Actually, I use it more for additional activities. As students have the opportunity to deal with different questions, I can direct questions to several students simultaneously..."

$\mathrm{M}_{4}$ : “... I generally use it while teaching something and solving questions..."

$\mathrm{M}_{5}$ : “... I usually use it for reviewing the lesson subjects or reinforcing a subject as well as solving questions towards the end of a lesson...”

$\mathrm{M}_{6}$ : “... Mostly, I use the traditional blackboard while teaching the lesson subjects, but I use the interactive whiteboard when I start solving questions. I mean I use it to do extra activities and to review the subjects..."

$\mathrm{M}_{7}$ : “... I use the interactive whiteboard to drawing the students' attention, to make effective use of the class time, to maintain students' motivation, to accelerate the learning process and to concretize what I taught them in class..." 


\section{Conclusions and Suggestions}

As use of interactive whiteboards is new at secondary schools, this study on the use of interactive whiteboards is very important in terms of knowing the effects of using interactive whiteboards in mathematics lessons for sustainability, revealing teachers' views about interactive whiteboards and increasing the efficiency of the attempts related to the use of interactive whiteboards. In this respect, the purpose of the present study was to determine the use of the interactive whiteboard in mathematics and to examine its effects on the role of teachers who are users of interactive whiteboards in class.

In line with this purpose, striking results were obtained via the interviews held with eight teachers regarding the categories of "The changes caused by interactive whiteboards in the process of teaching mathematics", "The facilities provided by the system for mathematics teachers", "The effects of using interactive whiteboards in teaching mathematics on the role of teachers", "The preparations for using interactive whiteboards in teaching mathematics", "Use of computer software with interactive whiteboards in teaching mathematics”.

It was found that use of interactive whiteboards had positive influences on variables such as students' motivation, their attitudes towards mathematics and their academic achievement in the course. Torff \& Tirotta (2010) pointed out that in their study the use of interactive whiteboards increased the students' motivation. In another study carried out by Tataroglu (2009), it was revealed that use of interactive whiteboards had positive influences on the students' attitudes towards mathematics and increased their academic achievement. However, it could be stated that use of interactive whiteboards had positive influences on the academic achievements of the students who were over a certain level of academic achievement.

The fact that use of interactive whiteboards in mathematics had positive influences on the students' attitudes towards mathematics could be explained both with the students' familiarity with current technology and with the frequent use of technology in a number of activities. In addition, it could be stated that use of interactive whiteboards increases visual quality, concretization and the number of questions solved and that this increase is in favour of students with higher levels of academic achievement. Although the teachers reported positive changes in terms of class management, it was seen that the students demonstrated undesirable behaviours because the secondary school mathematics teachers were not efficient in using interactive whiteboards and because the classrooms were crowded, which in turn led to negative influence on class management.

When the concepts taught in mathematics, which is a discipline based on abstract concepts, are not concretized, students fail to give meaning to the related concepts and cannot learn them. It could be stated that interactive whiteboards provide teachers with a number of facilities like providing visual quality regarding the concepts and subjects in mathematics, drawing figures properly, increasing students' participation in class by drawing their attention, supporting the lectures with presentations, solving questions in relation to the concepts taught in class, reviewing important points when necessary and allowing individual measurement and evaluation. There are a number of studies that point out that use of interactive whiteboards will provide positive contributions in several aspects (Altincelik, 2009; Bulut \& Kocoglu, 2012; Basibuyuk et al., 2014; Birisci \& Calik-Uzun, 2014; Coklar \& Tercan, 2014).

When the secondary school mathematics curricula in our Turkish education system are examined, it is clearly seen that mathematics teachers are supposed to undertake 
roles in accordance with the constructivist education philosophy. Based on the findings obtained in the present study, it could be stated that use of interactive whiteboards did not cause any change in the current role of secondary school mathematics teachers. However, use of interactive whiteboards could be said to strengthen certain aspects of that role including the ensuring of class management and discipline in class, allowing students to take a more active and efficient part in activities and guiding them in the learning and teaching process. In other words, use of interactive whiteboards in teaching mathematics has reduced the burden on teachers and become an assistive education tool for them.

In this study, it was found that the secondary school mathematics teachers did not use computer software during their classes. They did not use any computer software on the interactive whiteboards during their lessons because they did not have any knowledge about mathematical software; because they did not develop themselves in relation to the such software; because they did not receive any training on such software during their university education, and because those even previously knowledgeable about such software forgot how to use them in time.

Today, the mathematics curricula give importance to the use of technology in classes. Half $(\mathrm{N}=8)$ of the secondary school mathematics teachers participating in the present study reported that they used interactive whiteboards only for 1 to 2 course hours of a total of 5 weekly course hours. Considering the goals and objectives of the FATIH project, it could be stated that this amount of use of interactive whiteboards in class is not sufficient. The low frequency of the teachers' use of interactive whiteboards could be explained by the fact that the teachers had not received any training on the use of interactive whiteboards in mathematics during their university education. In addition, the teachers used interactive whiteboards for such purposes as drawing the students' attention and maintaining their motivation (4), teaching the lesson subjects (2), solving questions and doing additional activities (7) and reviewing the subjects. Considering these, the mathematics teachers used the interactive whiteboard in their classes mostly to solve questions and to do extra activities. It could be stated that use of the interactive whiteboard in education as a component of the FATIH project will not serve the purpose and may reduce the effectiveness of that project. It could also be stated that use of interactive whiteboards in mathematics mostly to solve questions and to do extra activities is due to the exam anxiety of the teachers, students and parents. In one study conducted by Turel (2012), it was pointed out that the teachers did not use interactive whiteboards in a way to serve the purposes of the whiteboards.

Consequently, although use of interactive whiteboards in teaching mathematics has various effects in several aspects, it could be stated that these interactive whiteboards are not used by secondary school mathematics teachers at the desired level. In addition, it was revealed that the teachers were not sufficiently informed about the use of interactive whiteboards, provided with the necessary related guidance or given any related inservice training they needed to use these whiteboards in their classes.

It is important that teacher training institutions provide preservice teachers with the necessary training on the use of interactive whiteboards. In addition, it is necessary to improve the in-service training given to current teachers regarding how to use interactive whiteboards in their classes. Also, it is important to provide this in-service training specific to the teaching fields of the teachers so that interactive whiteboards can be used more productively and effectively in classes. Moreover, teachers could be encouraged 
to use interactive whiteboards for other purposes besides doing additional activities and practices. Significantly, computer software which can be used for teaching mathematics could be included in interactive whiteboards, and teachers could be provided with training on the use of relevant software. In this study, the focus was on the secondary school teachers' use of interactive whiteboards and on the role of the teachers. Future studies could be designed using the quantitative approach in a way to involve secondary school students. Last of all, studies could be carried out focusing on different dimensions of teaching mathematics.

\section{References}

Akcayir, M. (2011). Akıll tahta kullanarak islenen matematik dersinin sinif ögretmenliği birinci sını ögrencilerin başari, tutum ve motivasyonlarma etkisi [The effect of using interactive whiteboard in mathematic lesson upon students' motivation, academic success and attitudes]. Yüksek Lisans Tezi, Gazi Üniversitesi Eğitim Bilimleri Enstitüsü, Ankara [Master Thesis, Gazi University, Graduate School of Educational Sciences, Ankara].

Alakoc, Z. (2003). Matematik öğretiminde teknolojik modern yaklaşımları [Technological modern teaching approaches in mathematics teaching]. The Turkish Online Journal of Educational Technology, 2(1), 43-49.

Aydin, S. (2016). Using excel in teacher education for sustainability. Journal of Teacher Education for Sustainability, 18(2), 89-104.

Badjanova, J., \& Ilisko, D. (2015). Holistic approach as viewed by the basic school teachers in Latvia. Discourse and Communication for Sustainable Education, 6(1), $132-140$.

Basibuyuk, K., Erdem E., Sahin, O., Gokkurt, B., \& Soylu, Y. (2014). Opinions of teachers and students about use of smart board in mathematics courses. Adiyaman University Journal of Educational Sciences, 4(2), 72-92.

Birisci, S., \& Uzun, S.Ç. (2014). Mathematics teachers' views on interactive whiteboard use in their courses: a sample of Artvin province. Elementary Education Online, 13(4), 1278-1295.

Cakula, S. (2011). Technological support and problem-based learning as a means of formation of student's creative experience. Discourse and Communication for Sustainable Education, 2(1), 46-55.

Çoklar, A. N., \& Kabakçi-Yurdakul, I. (2017). Technology integration experiences of teachers. Discourse and Communication for Sustainable Education, 8(1), 19-31.

Demir, S., \& Bozkurt, A. (2011). Primary mathematics teachers' views about their competencies concerning the integration of technology. Elementary Education Online, 10(3), 850-860.

Durak, H., Sarıtepeci, M., \& Çakır, H. (2016). An in-service training of teachers on the model proposal: web-based in-service professional development model. Journal of Computer and Education Research, 4(8), 222-248.

Egne, R. M. (2014). Gender equality in public higher education institutions of Ethiopia: The case of science, technology, engineering, and mathematics. Discourse and Communication for Sustainable Education, 5(1), 3-21.

Ekici, F. (2008). Akıll tahta kullanımının ilkögrretim öğrencilerinin matematik başarilarma etkisi [Effects of smart board usage on primary school maths students' 
success]. Yüksek Lisans Tezi, Marmara Üniversitesi, Eğitim Bilimleri Enstitüsü, İstanbul [Master Thesis, Marmara University, Graduate School of Educational Sciences, İstanbul].

Gerretson, H., Iliško, D., \& Fortino, C. (2010). Sustaining self-regulated student's learning through inquiry-driven mathematics and science instruction. Discourse and Communication for Sustainable Education, 1(1), 3-17.

Glover, D., \& Miller, D. (2002). Running with technology: The pedagogic impact of the large-scale introduction of interactive whiteboards in one secondary school. Technology Pedagogy and Education, 10(3), 257-278.

Gynne, A., \& Persson, M. (2018). Teacher roles in the blended classroom - Swedish lower secondary school teachers' boundary management between physical and virtual learning spaces. Journal of Computer and Education Research, 6(12), 222246.

Gündüz, S., \& Kutluca, T. (2019). Matematik ve fen bilimleri ögretiminde akıllı tabta kullanımının ögrencilerin akademik başarlarına etkisi üzerine bir meta-analiz çalışması [A meta-analysis study on the effect of the use of smart board in the teaching of mathematics and science to students' academic achievements]. Journal of Computer and Education Research, 7(13), 183-204. doi: 10.18009/jcer.533986

Kennewell, S., \& Beauchamp, G. (2007). The features of interactive white boards and their influence on learning. Learning, Media and Technology, 32(3), 227-241.

Kocak, O., \& Gulcu, A. (2013). Teachers' remarks on interactive whiteboard with lcd panel technology. International Journal of Education in Mathematics, Science and Technology, 1(4), 294-300.

Kutluca, T. (2009). İkinci dereceden fonksiyonlar konusu için tasarlanan bilgisayar destekli ögrenme ortamının değerlendirilmesi [Evaluation of a computer assisted learning environment designed for the subject of quadratic functions]. Doktora Tezi. Karadeniz Teknik Üniversitesi, Fen Bilimleri Enstitüsü, Trabzon [PhD Thesis, Karadeniz Technical University, Graduate School of Educational Sciences, Trabzon].

Kutluca, T. (2017). Views of mathematics teacher candidates about the technological tools that can be used in mathematics lessons. European Journal of Educational Research, 6(3), 321-330.

Makrakis, V., \& Kostoulas-Makrakis, N. (2012). Course curricular design and development of the M. Sc. Programme in the field of ICT in education for sustainable development. Journal of Teacher Education for Sustainability, 14(2), 5-40.

Mayer, R. E. (2003). The promise of multimedia learning: using the same instructional design methods across different media. Learning and Instruction, 13(2), 125-139.

Merriam, S. B. (2013). Nitel araştırma: desen ve uygulama için bir rebber [Qualitative research a guide to design and implementation]. Ankara: Nobel Akademik Yayıncıllk.

Ministry of National Education (MNE). (2013). Ortaokul matematik dersi (5, 6, 7 ve 8.sinflar) öğretim programi [Secondary Mathematics Education Program]. Talim ve Terbiye Kurulu Başkanlığı, Ankara: Milli Eğitim Basımevi.

National Council of Teachers of Mathematics (NCTM). (2000). Principles and standards for school mathematics. Reston, VA: The National Council of Teachers of Mathematics.

Salite, I. (2015). Searching for sustainability in teacher education and educational research: Experiences from the Baltic and Black Sea Circle Consortium for educational research. Discourse and Communication for Sustainable Education, 6, 21-29. 
Saraç, H., \& Özarslan, M. (2017). Fen alanı öğretmen adaylarının bilgi ve iletişim teknolojilerine yönelik görüşleri [Views of science fields teacher's necessaries to information and communication technologies]. International e-Journal of Educational Studies (IEJES), 1(1), 32-46.

Tataroglu, B. (2009). Matematik ögrretiminde akıll tahta kullanımını 10. sinı öğrencilerinin akademik başarları, matematik dersine karşı tutumları ve öz-yeterlik düzeylerine etkileri [The effect of utilizing the smart board in mathematics teaching on $10^{\text {th }}$ grade students, their academic standings, their attitude towards mathematics and their self efficacy levels]. Yayınlanmamış Yüksek Lisans Tezi, Dokuz Eylül Üniversitesi Eğitim Bilimleri Enstitüsü, İzmir [Master Thesis, Dokuz Eylül University, Graduate School of Educational Sciences, İzmir].

Torff, B., \& Tirotta, R. (2010). Interactive whiteboards produce small gains in elementary students' self-reported motivation in mathematics. Computers \& Education, 54(2), 379-383.

Turel, Y. K. (2012). Öğretmenlerin akıllı tahta kullanımına yönelik olumsuz tutumları: problemler ve ihtiyaçlar [Teachers' negative attitudes towards interactive whiteboard use: needs and problems]. Elementary Education Online, 11(2), 423-439.

Yilmaz, M. (2007). Sınıf öğretmeni yetiştirmede teknoloji eğitimi [Instructional technology in training primary school teacher]. Gazi University Journal of Faculy Education, 27(1), 155-167.

Correspondence concerning this article should be addressed to Assoc. Prof. Dr. Tamer Kutluca, Dicle University College Education, Departments of Mathematics Education, Turkey.E-mail: tkutluca@dicle.edu.tr 